\title{
PERBANDINGAN BENTUK TINDAK TUTUR MEMINTA OLEH PEMBELAJAR BIPA DARI KOREA DAN PENUTUR ASLI BAHASA INDONESIA: KAJIAN BAHASA ANTARA
}

\author{
Adista Nur Primantari' ${ }^{1}$ dan Prof. Dr. I Dewa Putu Wijana, S.U., M.A. ${ }^{2}$ \\ ${ }^{1}$ Pusat Pengembangan Strategi dan Diplomasi Kebahasaan, Badan Pengembangan dan \\ Pembinaan Bahasa Kementerian Pendidikan dan Kebudayaan \\ dista_np@yahoo.com \\ ${ }^{2}$ Fakultas Ilmu Budaya Universitas Gadjah Mada \\ idp_wijana@yahoo.com
}

\begin{abstract}
This study is aimed at comparing the form of request utterances in bahasa Indonesia produced by Korean learners of Indonesian with the native speakers. Data in this research were collected through a direct fieldwork by recording and taking notes on conversations produced by Korean learners of Indonesian in Yogyakarta. After collecting the data, we analyze them through comparison of the data between the Korean and Indonesian speakers. It turns out that the Korean learners of Indonesian produce different request utterance forms compared to the native speakers. The patterns of the request utterances can be seen in three different forms: the structure, the variation, and the strategy of the utterances. The difference between utterances produced by the learners and the native speakers found in the choice of formal and informal styles, strategy of request, semantic formulas, and personal pronouns.
\end{abstract}

Keywords: Interlanguage, Bahasa Indonesia, Korean learners of Indonesian

\begin{abstract}
Abstrak
Kajian ini bertujuan untuk membandingkan bentuk tuturan meminta dalam bahasa Indonesia yang dihasilkan oleh pembelajar BIPA dari Korea dengan bentuk tuturan yang diproduksi oleh penutur asli bahasa Indonesia. Objek kajian iniadalah bahasa antara. Data dalam penelitian ini diperoleh melalui penelitian lapangan dengan cara mengambil data secara langsung, baik melalui teknik rekam dan catat dari percakapan yang doproduksi oleh pembelajar BIPA dari Korea di Yogyakarta. Setelah data terkumpul, peneliti meenganalisisnya dengan cara membandingkannya dengan tuturan meminta yang diproduksi oleh penutur asli bahasa Indonesia. Hasil dari kajian ini menunjukkan bahwa pembelajar BIPA dari Korea memproduksi tuturan yang berbeda dengan bahasa Indonesia yang diproduksi oleh penutur asli. Pola tuturan meminta yang diproduksi oleh pembelajar BIPA dari Korea ini dapat dilihat dari tiga bentuk, yaitu struktur, variasi, dan strategi tuturan. Perbedaan antara tuturan meminta yang diproduksi oleh pembelajar BIPA dari Korea dengan penutur asli bahasa Indonesia ditemukan pada pemilihan bentuk tuturan yang formal dan nonformal, strategi meminta, formula semantic, dan pronominal personal.
\end{abstract}

Kata kunci: Bahasa antara, bahasa Indonesia untuk Penutur Asing, pembelajar BIPA dari Korea. 


\section{Pendahuluan}

Meminta (request) bukanlah hal yang mudah dilakukan. Tindak tutur meminta mengandung daya ilokusioner. Bentukbentuk tuturan yang berbeda banyak ditemukan dalam tuturan meminta yang diproduksi oleh pembelajar BIPA dari Korea (PBK) ketika menggunakan bahasa Indonesia. Sebagian besar dari perbedaan tersebut menyebabkan tuturannya tidak mematuhi kesantunan dalam bahasa Indonesia. Perbedaan-perbedaan tersebut dapat menyebabkan penyimpangan dan menjadi penyebab utama yang menyebabkan kegagalan dan kesalahpahaman dalam komunikasi. Beberapa perbedaan bentuk tersebut mengakibatkan tuturan meminta PBK dilabeli oleh penutur asli sebagai tidak sesuai, bahkan tidak santun digunakan dalam sebuah tindak tutur. Tidak dapat dipungkiri bahwa bentuk-bentuk yang berbeda tersebut terbentuk karena kemampuan gramatikal PBK belum memadai. Akan tetapi, adanya transfer negatif dari sistem pragmatik bahasa Korea, interferensi budaya Korea, dan beberapa faktor nonlinguistik, seperti lingkungan pembelajaran bahasa Indonesia, pergaulan, dan kebiasaan ikut berperan sebagai faktor yang menyebabkan perbedaan bentuk tuturan meminta yang dihasilkan oleh PBK. Berdasarkan latar belakang di atas, permasalahan dalam penelitian ini adalah sebagai berikut. Pertama, bagaimana bentuk tuturan meminta dalam bahasa Indonesia yang dihasilkan oleh pembelajar BIPA dari Korea? dan kedua, bagaimana bentuk tuturan meminta yang dihasilkan oleh penutur asli bahasa Indonesia?

Kajian mengenai tindak tutur permintan dalam bahasa Indonesia sudah dikaji oleh Pratita (1999). Namun, kajian tersebut memfokuskan perhatiannya pada kinerja verbal tindak tutur permintaan pada teori Blum-Kulka yang menguraikan bentuk ujaran untuk menyuruh. Penelitian tersebut menyimpulkan bahwa ada sebelas pola untuk meminta dalam bahasa Indonesia, yaitu (1) tuturan bermodus imperatif, (2) tuturan performatif eksplisit, (3) tuturan berpagar, (4) tuturan preposisi keharusan, (5) tuturan menunjukkan kesangsian, (6) tuturan pengandaian bersyarat, (7) tuturan proposisi yang menggunakan impersona, (8) tuturan menyertakan alasan, (9) tuturan terselubung, (10) tuturan sindiran, dan (11) tuturan kelakar.

Dalam sebuah penelitian yang lebih luas mengenai kajian imperatif dalam bahasa Indonesia, Rahardi (1999) menyatakan bahwa permintaan termasuk ke dalam salah satu wujud pragmatik imperatif. Wujudwujud pragmatik imperatif yang lain adalah perintah, suruhan, permohonan, desakan, bujukan, himbauan, persilaan, ajakan, izin, mengizinkan, larangan, harapan, umpatan, pemberian ucapan selamat, anjuran, dan ngelulu. Hal-hal penanda kesantunan dalam tuturan imperatif bahasa Indonesia meliputi panjang pendeknya tuturan, urutan tutur, intonasi dan isyarat kinesik, dan adanya ungkapan-ungkapan penanda kesantunan. Selain itu, dirumuskan bahwa dalam bahasa Indonesia, permintaan yang santun dapat dinyatakan dalam tuturan deklaratif dan tuturan interogatif.

Tanaka (1988) dalam Nadar (2009) melakukan penelitian kontrastif tentang kesantunan berbahasa orang-orang Jepang yang mampu berbicara bahasa Inggris. Dengan menggunakan teori Brown dan Levinson (1978), kesantunan berbahasa orang Jepang dibandingkan dengan warga Australia. Hasil penelitian ini menunjukkan bahwa dibandingkan mahasiswa Australia, mahasiswa Jepang cenderung menggunakan strategi kesantunan tertentu yang tidak variatif dan kaya sebagaimana yang digunakan oleh mahasiswa Australia. Mahasiswa Jepang juga cenderung tidak memanggil mitra tutur, kurang eksplisit membuat tuturan permintaan, dan cenderung berbicara secara lebih formal.

Kemampuan mahasiswa asing yang belajar bahasa Indonesia juga diteliti oleh Zubaidi (2013) yang mengadakan penelitian tentang "Realisasi Keluhan oleh Pembelajar 
Asing Bahasa Indonesia: Kajian Pragmatik Bahasa Antara (Interlanguage Pragmatics)". Penelitian ini menyatakan bahwa strategi keluhan yang dipilih mahasiswa Amerika dalam mengeluh dalam bahasa Indonesia, meliputi (1) isyarat, (2) tuduhan langsung, (3) tuduhan tidak langsung, (4) konsekuensi buruk, (5) hukuman eksplisit terhadap pihak yang mendapatkan keluhan, (6) hukuman eksplisit terhadap pihak yang mendapatkan keluhan sebagai persona, (7) celaan termodifikasi, dan (8) kejengkelan. Selain itu, pemilihan strategi keluhan juga dikaitkan dengan faktor sosial yang melatarbelakangi penutur dan konteks tuturan.

Teori yang digunakan untuk menganalisis data dalam penelitian ini meliputi teori mengenai pragmatik bahasa antara (interlanguage pragmatics) dan teori mengenai tindak tutur meminta. Kedua teori tersebut saling dikaitan untuk menjawab rumusan masalah dalam penelitian yang mengkaji perbedaan bentuk-bentuk tuturan meminta dalam bahasa Indonesia yang diproduksi oleh pembelajar BIPA dari Korea ini.

Penelitian ini termasuk dalam studi pragmatik bahasa antara. Pada umumnya, studi mengenai bahasa antara berkaitan dengan kemampuan pembelajar bahasa kedua dalam menggunakan kemampuan pada ranah fonologi, morfologi, dan sintaksis. Akan tetapi, kemudian mucul bidang baru yang disebut pragmatik bahasa antara, yaitu suatu bidang yang menggabungkan studi mengenai pembelajaran bahasa kedua dengan studi pragmatik. Pragmatik bahasa antara adalah sebuah studi mengenaibagaimana pembelajar bahasa kedua menggunakan kemampuan pragmatik dan pemahaman wacananya untuk berkomunikasi pada bahasa kedua. Studi tentang budaya cara bertutur yang berbeda disebut pragmatik kontrastif. Secara lebih lanjut, studi kontrastif ini dilakukan dalam pragmatik lintas budaya yang menjelaskan perbedaan-perbedaan cara bertutur berdasarkan perbedaan budaya. Akan tetapi, jika penelitian kontrastif tersebut difokuskan secara lebih khusus pada tingkah laku komunikatif dari orang yang bukan penutur asli saat berkomunikasi dalam bahasa kedua dan membandingkannya dengan tingkah laku komunikatif penutur asli, penelitian tersebut dideskripsikan sebagai pragmatik bahasa antara (Yule, 1996).

Studi pragmatik bahasa antara berkaitan dengan performansi dan pemerolehan kemampuan pragmatik dalam pembelajaran bahasa kedua. Oleh karena berkaitan dengan dua bahasa yang berbeda, studi ini juga berkaitan dengan pola linguistik dan pola budaya yang berbeda pula. Sejumlah kajian pragmatik bahasa antara telah diterapkan pada berbagai bahasa, baik itu berupa studi sinkronis maupun perkembangan. Istilah bahasa antara atau interlanguage pertama kali digunakan oleh Selinker pada tahun 1969. Dalam proses pembelajaran bahasa kedua atau bahasa asing, pembelajar akan mengalami tahapan proses psikolinguistik sebelum mereka memperoleh bahasa keduanya. Performansi pembelajar yang belum sempurna dan belum mencapai kompetensi dalam bahasa sasaran akan ditandai dengan adanya bentuk-bentuk yang menyimpang dari kaidah bahasa target. Tahapan itu disebut interlanguage atau bahasa antara. Bahasa antara bersifat independen, yaitu tidak berkaitan dengan bahasa pertama dan juga tidak berkaitan dengan bahasa kedua walaupun kadangkala memperlihatkan pengaruh dari keduanya. Ketika si terdidik mentransformasi dan menghasilkan pola-pola bahasa akibat aktivitas belajarnya, pengaruh dari bahasa pertama selalu muncul. Pola-pola pada bahasa kedua yang dipengaruhi oleh bahasa pertama disebut bahasa antara (Selinker dalam Pateda, 1989, p.73).

\section{Metode}

Penelitian pragmatik bahasa antara ini memilih menggunakan tindak tutur meminta untuk menguji kemampuan bahasa Indonesia pembelajar bahasa Indonesia dari Korea. Ada beberapa alasan mengapa penelitian ini 
memfokuskan analisis penyimpangan bahasa antara pada tindak tutur meminta. Pertama, permintaan adalah tindak tutur yang sangat berguna dan sering terjadi dalam komunikasi, khususnya bagi pembelajar bahasa asing. Kedua, dibandingkan dengan tindak tutur yang lain, tindak tutur meminta adalah salah satu jenis tindak tutur yang paling banyak dipelajari di dalam pembelajaran bahasa asing. Ketiga, tindak tutur meminta yang dinyatakan dalam konteks-konteks tertentu dapat digunakan untuk menginvestigasi perkembangan kemampuan pragmatik pembelajar (Achiba, 2003).

Data dalam penelitian ini diperoleh melalui penelitian lapangan dengan cara mengambil data secara langsung, baik melalui teknik rekam dan catat dari percakapan yang doproduksi oleh pembelajar BIPA dari Korea di Yogyakarta. Setelah data terkumpul, peneliti meenganalisisnya dengan cara membandingkannya dengan tuturan meminta yang diproduksi oleh penutur asli bahasa Indonesia.

Permintaan merupakan sebuah ekspresi yang di dalamnya terkandung suatu maksud agar mitra tutur bertindak. Sebuah permintaan dapat diwujudkan dalam kalimat imperatif, interogatif, dan deklaratif (Wierzbicka, 1991, p.88). Pemilihan modus kalimat dalam melakukan permintaan berkaitan dengan strategi. Blum-Kulka et al (1989) mengklasifikasikan strategi permintaan menjadi tiga, yaitu (1) strategi langsung (direct strategies), (2) strategi tidak langsung (conventionally indirect strategies), dan (3) strategi isyarat (nonconventionally indirect strategies/hints). Permintaan dikatakan langsung jika modus kalimat yang digunakan adalah imperatif sedangkan permintaan dikatakan tidak langsung jika modus kalimat yang digunakan adalah bukan imperatif, melainkan deklaratif dan interogatif (Wijana, 1996 p.29).

Perbedaan-perbedaan bentuk tuturan meminta yang dihasilkan oleh pembelajar dan penutur asli tersebut dapat terlihat dari bentuk tuturan yang dihasilkan. Pada umumnya, perbedaan terletak pada pemilihan strategi meminta dan elemenelemen yang digunakan untuk menyusun tuturan permintaan. Perbedaan ini berkaitan dengan budaya asli dan transfer negatif dari B1 pembelajar. Jika tidak diperhatikan penggunaannya, perbedaan tersebut dapat mengancam muka penutur dan melanggar kesantunan dalam bahasa Indonesia. Oleh karena itu, penelitian ini dikaitkan juga dengan teori mengenai kesantunan lintas budaya.

\section{Hasil Dan Pembahasan}

Bentuk-bentuk tuturan meminta (TTM) yang dihasilkan oleh pembelajar BIPA dari Korea (PBK) dianalisis dengan cara dipandang dari tiga sektor, yaitu struktur tutur, variasi tutur, dan strategi tuturnya.

\subsection{Struktur Tutur}

Analisis struktur tutur, yaitu kajian terhadap kehadiran dan posisi tindakan pokok dan tindakan pendukung TTM. Kehadiran dan posisi tindakan pokok dan tindakan pendukung yang diproduksi oleh PBK dalam penelitian ini dibedakan menjadi lima bagian, yaitu (1) tindakan pokok saja, (2) tindakan pokok diikuti tindakan pendukung, (3) tindakan pendukung diikuti tindakan pokok, (4) tindakan pokok diapit tindakan pendukung, dan (5) tindakan pendukung saja. Berikut ini adalah bentukbentuk tuturan meminta PBK dilihat dari struktur tuturnya. 
Boleh pinjam pena? T. Pkok

Konteks: PBK meminjam pena kepada adik kelas.

Boleh meminjamkan pena? Saya tidak ada pena.

$$
\text { T.Pokok T.Pendukung }
$$

Konteks: PBK meminjam pena kepada adik kelas.

Halo. Kamu ingat aku? Kita pernah ambil kelas yang sama dulu. Sebenarnya, aku perlu telepon dosen X. Tapi nomor hapenya terhapus tiba-tiba. Kalo kamu masih

T.Pendukung T.Pokok

punya nomor dosen $\mathrm{X}$, boleh tahu nomor dosen X?

Konteks: PBK meminta nomor telepon dosen kepada adik kelasnya.

Eh, kamu lagi pakai apa? Boleh saya coba? Sebenarnya saya sekarang merasa kulitku
T.Pendukung
T. Pokok
T. Pendukung

kering, perlu lotion.

Konteks: PBK meminta krim tabir surya yang dimiliki oleh teman dekatnya.

Uwaah, kok kotor banget ya!

T.Pendukung

Konteks: PBK meminta teman sekamarnya untuk membersihkan kamar yang kotor.

\subsection{Variasi Tutur}

Bentuk-bentuk permintaan yang dipandang dari variasi tuturnya dibedakan menjadi bentuk tuturan yang memiliki (1) ragam formal dan informal dan bentuk tuturan yang mengandung (2) alih kode dalam bahasa Korea dan alih kode dalam bahasa Inggris.

\subsubsection{Ragam Formal dan Informal}

Ragam permintaan yang dihasilkan oleh PBK ditemukan pada ragam formal dan informal. Keformalan atau ketidakformalan sebuah ragam dapat dilihat dari kelengkapan dan kejelasan ujarannya. Ragam formal adalah ragam yang menggunakan bentuk kalimat lengkap dan jelas sedangkan ragam informal adalah ragam yang menggunakan bentuk kalimat yang kurang lengkap. Pada ragam informal ini umumnya ada pelesapan kata atau suku kata atau bahkan ada penambahan hal-hal yang tidak perlu (Revita, 2007:198). Oleh karena itu, bentuk tuturan yang memiliki ragam formal bentuknya cenderung lebih panjang daripada bentuk tuturan yang memiliki ragam informal. Kedua ragam tersebut dapat dilihat pada data berikut.

\section{a. Ragam Formal}

"Selamat pagi, Profesor Putu. Nama saya Lee Junghoon yang mengikuti kuliah profesor, bahasa Indonesia. Saya ke sini karena mau diskusikan sesuatu. Sebenarnya minggu depan kakak saya menikah, jadi saya berencana ikut rencana itu, tetapi ternyata minggu depan ada ujian bahasa Indonesia juga. Saya agak berat kalau ikut ujian dan ikut upacara pernikahan juga. Apakah boleh saya duduk ujian habis selesai upacara pernikahan?"

Konteks: PBK meminta ujian susulan kepada profesor yang mengampu mata kuliahnya karena kakak PBK menikah bertepatan dengan hari diselenggarakan ujian. 


\section{b. Ragam Informal}

"Hei, bersihin kamarnya atau panggil pembantu!"

Konteks: $P B K$ meminta teman sekamarnya untuk membersihkan kamar yang kotor.

"Puput aku juga mau, dong."

Konteks: PBK meminta krim tabir surya yang dimiliki oleh teman dekatnya.

\subsubsection{Alih Kode dalam Bahasa Korea dan} bahasa Indonesia

Ada dua kode yang menyebabkan variasi tuturan permintaan PBK, yaitu kode dalam bahasa Korea dan kode dalam bahasa Inggris. Alih kode dalam penelitian ini dilakukan PBK selain untuk menyampaikan maksud tertentu, juga sebagai penanda ketidakmampuan PBK dalam menggunakan kode bahasa Indonesia. alih Kode dalam bahasa
Korea

"Ah, jajjeungna! Aku lupa membawa krim tabir surya hari ini. Puput, boleh aku pakai krim kamu sedikit? Minta maaf. Terima kasih."

Konteks: PBK meminta krim tabir surya yang dimiliki oleh teman dekatnya.

\section{b. Alih Kode dalam bahasa Inggris}

"Profesor, apa kabar? Maaf saya lama tidak datang. I'm here to ask your opinion on my scholarship recommendation. Anda adalah mentor paling baik saya, so I have been thinking that you would give me some advices. I've been interested in this program so much. Would you please write a recommendation for me? It will help me to get the scholarship and study more about the Anthropology. Terima kasih, Profesor."

Konteks: PBK meminta profesor yang dikenal dengan baik untuk memberikan surat rekomendasi beasiswa.

\section{c. Strategi Tutur}

Bentuk TTM yang dilihat dari strategi tuturnya dibedakan menjadi modus kalimat, cara, dan tipe tuturan.

\subsubsection{Modus Kalimat}

Secara sintaksis, berdasarkan fungsinya dalam hubungan konteks, modus kalimat dalam tuturan meminta PBK dapat digolongkan menjadi empat golongan, yaitu kalimat deklaratif (kalimat berita), kalimat interogatif (kalimat tanya), kalimat imperatif (kalimat suruh), dan kalimat eksklamatif (kalimat seru). Berikut ini adalah bentuk tuturan meminta yang diwujudkan dalam keempat kalimat tersebut.

\section{a. Kalimat Deklaratif}

"Sinta, kita harus membersihkan kamar kita. Ada banyak sampah dalam kamar."

Konteks: PBK meminta teman sekamar untuk membersihkan kamar yang kotor.

\section{b. Kalimat Interogatif}

"Permisi, Paman, boleh saya tanya? Kalau saya ke jalan $X$, bagaimana ya?"

Konteks: PBK meminta informasi letak kos teman dengan bertanya kepada orang asing yang ditemui di jalan. 


\section{c. Kalimat Imperatif}

“Tolong beritahu nomor telepon dosen! Nomornya terhapus dari hapeku." Konteks: PBK meminta nomor telepon dosen kepada adik kelas.

\section{c. Kalimat Eksklamatif}

"Uwaah, kok kotor banget ya!"
Konteks: PBK meminta teman sekamarnya untuk membersihkan kamar

\subsubsection{Cara}

Ada 16 cara yang dilakukan oleh PBK untuk meminta dalam bahasa Indonesia. Cara-cara tersebut dapat dilihat dalam tuturan-tuturan berikut.

\section{Cara}

\section{Tuturan}

(1) Kalimat bermodus imperatif (mood-derivable)

(7) Hei, bersihin kamarnya atau panggil pembantu!

(2) Performatif eksplisit (performative)

(14) Puput, minta pinjam kirimmu, saya tinggalan itu di rumah

(3) Performatif berpagar (hedged performative)

(15) Sebenarnya, aku perlu nomor telepon dosen X.

(4) Pernyataan keharusan (locution-derivable)

(16) Kamu harus bertanggung jawab tentang ini. Kamu dan temanmu sudah dewasa, kan? Bukan anak kecil. Seharusnya membersihkan kamar ini.

(5) Pernyataan keinginan (want-statement)

(17) Permisi Pak, Saya Kim jurusan Sastra Indonesia. Saya sangat ingin ikut kuliah Bapak. Boleh izin tambahkan saya?

(6) Rumusan saran (suggestory formula)

(7) Persiapan pertanyaan (query-preparatory)

(8) Isyarat (hint)

(9) Mengajak

(10) Menawarkan

(11) Melarang

(18) Sinta, lihat ini! Ada banyak sampah selama semalam. Sebaiknya kita bersihkan kamar bersama. Itu akan lebih cepat.

(19) Sinta, Boleh membersihkan kos? Ada banyak sampah-sampah.

(5) Uwaah, kok kotor banget, ya!

(20) Sinta, mari kita membersihkan kamar kita. Kamar ini bukan kamar untuk seroang raja, tetapi kamar kami dua orang, benar ya? Ayo aku akan membantumu juga. (21) Hmm, Sinta, lihat ini! Ada banyak sampah seperti ini. Bagaimana kita bersama membersihkan ini semua?

(22) Yaa! Jangan ganggu saya!

Selamat pagi, Pak Putu. Apa kabar? Saya juga baikbaik, terima kasih. Pak, hari ujian kelas Bahasa adalah hari menikah kakak saya. Jadi boleh saya mengetes satu hari sebelum hari ujian? Semoga bapak memberikan keizinan untuk saya.

(24) Selamat pagi, Pak Putu. Nama saya Lee Junghoon yang mengikuti kuliah Bapak, bahasa Indonesia. Saya ke sini karena mau diskusikan sesuatu. Sebenarnya minggu depan kakak saya menikah, jadi saya berencana ikut rencana itu, tetapi ternyata minggu depan ada ujian bahasa Indonesia juga. Saya agak berat kalau ikut ujian dan ikut upacara pernikahan juga. Apakah boleh saya duduk ujian habis selesai upacara pernikahan?

(14) Menggunakan imperatif halus (25) Hai, Dian, Aku sekarang lelah sekali. Tolong bonceng aku kalau kamu tidak keberatan. 


\section{Cara}

(15) Menggunakan rumusan izin
Tuturan

(26) Selamat siang Bapak Suhandano. Nama saya Lisa dari jurusan Bahasa Indonesia. Saya datang di sini untuk meminta keizinan untuk mengikuti kelas bapak. Saya sudah tahu kuota mahasiswa kelas itu sudah habis, tapi saya sangat ingin belajar Kebudayaan Indonesia pada semester ini karena saya pulang ke Korea setelah semester ini. Bapak, minta keizinan untuk mengikuti kuliah itu.

(27) Aduh, nomor Pak Putu terhapus dari hapeku. Aduh. Eh, minta maaf, apa Anda punya nomor hape dosen itu? Boleh saya minta nomor hapenya? Terima kasih.

\subsubsection{Tipe Tuturan}

Tipe tuturan yang ditemukan dalam tuturan meminta PBK dibedakan menjadi empat tipe, yaitu tuturan langsung, tuturan tidak langsung, tuturan literal, dan tuturan nonliteral.
Tipe

Tuturan langsung

Tuturan tidak langsung

Tuturan literal

Tuturan nonliteral

\section{Tuturan}

(28) Puput minta pinjam kirimmu! Saya tinggalan itu di rumah.

(29) Nita, laptopku tiba-tiba mati dan tidak bias hidup lagi. Besok pagi aku harus mengumpulkan tugas. Aku tidak punya waktu untuk membaiki laptop sekarang.

(30) Halo! Minta maaf, nama saya Lisa. Hari ini saya lupa membawa penaku, maka boleh Anda meminjamkan pena Anda sebentar? Maaf.

(31) Minta maaf, saya sekarang sangat sibuk dan tidak ada waktu untuk Anda. Minta maaf lagi. Minta pergi saja.

\subsubsection{Bentuk Tuturan Meminta oleh Penutur Asli Bahasa Indonesia}

Samahalnya dengan bentuk permintaan oleh PBK, bentuk-bentuk tuturan meminta yang dihasilkan oleh penutur asli pada bab ini juga dianalisis berdasarkan tiga sektor, yaitu struktur tutur, variasi tutur, dan strategi tuturnya. Sama halnya dengan struktur tuturan meminta yang dihasilkan oleh PBK, kehadiran dan posisi tindakan pokok dan tindakan pendukung yang diproduksi oleh penutur asli dalam penelitian ini ditemukan dalam lima struktur, yaitu (1) tindakan pokok saja, (2) tindakan pokok diikuti tindakan pendukung, (3) tindakan pendukung diikuti tindakan pokok, (4) tindakan pokok diapit tindakan pendukung, dan (5) tindakan pendukung saja.
Dilihat dari variasi tuturnya, ragam permintaan yang dihasilkan oleh penutur asli ditemukan pada ragam formal dan informal. Tidak ditemukan alih kode ke dalam bahasa daerah atau ke dalam bahasa asing.

Dilihat dari strategi tuturnya, tuturan meminta yang dihasilkan oleh penutur asli juga diwujudkan ke dalam empat modus kalimat, yaitu kalimat deklaratif, kalimat interogatif, kalimat imperatif, dan kalimat eksklamatif. Penutur asli memiliki cara meminta yang lebih banyak daripada yang digunakan oleh PBK. Ada 21 cara yang dilakukan oleh penutur asli untuk meminta sedangkan PBK hanya menggunakan 16 cara meminta. Ada lima cara yang berbeda, yaitu menggunakan bentuk pasif, melekatkan partikel $-k a h$, melekatkan imbuhan meN- 
pada kata kerja, menggunakan pengandaian, bentuk-bentuk tuturan penutur asli yang dan menggunakan pujian. Berikut ini adalah diwujudkan dalam kelima cara tersebut.

\begin{tabular}{ll}
\hline \multicolumn{1}{c}{ Cara } & \multicolumn{1}{c}{ Tuturam } \\
\hline & (32) Mohon maaf Bapak, apakah diperbolehkan jika \\
& saya mengumpulkan tugas besok pagi? \\
& (33) Eh, apa itu Put? Wah, boleh mintakah? Aku lupa \\
(18) Melekatkan partikel -kah & pakai tabir surya padahal cuaca panas banget. \\
& (34) Selamat siang, Prof. Saya bermaksud \\
(19) Melekatkan imbuhan $m e N$ - pada kata kerja & $\begin{array}{l}\text { mengikuti kuliah Bahasa Indonesia karena kakak } \\
\text { saya melangsungkan pernikahan di hari yang sama. }\end{array}$ \\
& Apakah saya boleh mengikuti ujian susulan, Prof? \\
(20) Menggunakan pengandaian & (35) Panas, ya Put, seandainya ada yang bagi-bagi \\
krim, ya. & Put, bagi krimnya dikit, dong! Boleh, ya? Boleh, dong, \\
(21) Memuji & 'kan kamu baik hati dan tidak sombong. \\
\hline
\end{tabular}

Dilihat dari tipe tuturnya, tuturan meminta yang dihasilkan oleh penutur asli juga diwujudkan ke dalam empat tipe tuturan, yaitu tuturan langsung, tuturan tidak langsung, tuturan literal, dan tuturan nonliteral.

\section{Simpulan}

Realisasi tindak tutur meminta (TTM) yang dihasilkan oleh pembelajar BIPA dari Korea (PBK) apabila dibandingkan dengan penutur asli bahasa Indonesia dapat dilihat dari tiga bentuk, yaitu dari variasi tuturnya, strategi tutur, dan struktur tuturnya. Hal ini Bentuk perbedaan TTM yang dihasilkan oleh pembelajar BIPA dari Korea (PBK) dan TTM yang dihasilkan oleh penutur asli ditemukan pada pemilihan ragam formal dan informal, pada pemilihan strategi meminta, pada pemilihan formula semantik, dan pada pemilihan pronomina persona.

\section{Daftar Pustaka}

Achiba, Machiko. (2003. Learning to Request in a Second Language. Clevedan: Multilingual Matters.

Blum-Kulka, Shoshana, Juliane House, dan Gabriele Kasper. (1987). Cross-cultural Pragmatics: Request and Apologies. New Jersey: Ablex Publishing Corporation.

Blum-Kulka, Shoshana dan Gabriele Kasper. (1993). Interlanguage Pragmatics. Oxford: Oxford University Press.

Brown, Penelope and Stephen Levinson. (1987). Politeness: Some Universals in Language Usage. Cambridge: Cambridge University Press.

Lee, Iksop dan Robert Ramsey. (2000). The Korean Language. Albany: State University of New York.

Nadar, Franciscus Xaverius. (2006). "Penolakan dalam Bahasa Inggris dan Bahasa Indonesia: Kajian Pragmatik tentang Realisasi Strategi Kesopanan Berbahasa”. Disertasi. Fakultas Ilmu Budaya Universitas Gadjah Mada.

Park, J. (2001). "Korean EFL Learners' Politeness Strategies in Their Complaints" dalam The Lingustic Association of Korea Journal, 9 (1) halaman 185-209. 
Pateda, Mansoer. (1989). Analisis Kesalahan. Flores: Nusa Indah.Pratita, Ina Ika. 1999. "Tindak Tutur Permintaan dalam Bahasa Indonesia: Studi Kasus Tindak Tutur pada Ranah Keluarga di Surabaya”. Tesis. Tidak Diterbitkan. Yogyakarta: Universitas Gadjah Mada

Primantari, Adista Nur. (2012). "Analisis Kesalahan Berbahasa Indonesia pada Tataran Sintaksis oleh Pembelajar BIPA dari Korea”. Skripsi. Tidak Diterbitkan. Jurusan Sastra Indonesia, Fakultas Ilmu Budaya, Universitas Gadjah Mada Yogyakarta.

Rahardi, Kunjana Remigius. (1999). "Imperatif dalam Bahasa Indonesia: Kajian Pragmatik tentang Kesantunan Berbahasa". Disertasi. Tidak Diterbitkan. Universitas Gadjah Mada Yogyakarta.

Sukamto, Katharina Endriati. (2012). "Polite Request by Korean Learnes of Indonesian" dalam Studies in Literature and Language Vol. 5, No. 2, Hal. 1-9. Canadian Academy of Oriental and Occidental Culture.

Wierzbicka, Anna. (1991). Cross-cultural Pragmatics. Berlin: Moyton de Gruyter. Wijana, I Dewa Putu. 1996. Dasar-dasar Pragmatik. Yogyakarta: Andi.

Yule, George. (1996). Pragmatik. Yogyakarta: Pustaka Pelajar.

Zubaidi, Nanang. (2013). "Realisasi Keluhan oleh Pembelajar Asing Bahasa Indonesia: Kajian Pragmatik Bahasa Antara (Interlanguage Pragmatics)". Tesis. Program Pascasarjana Program Studi Linguistik Fakultas Ilmu Budaya Universitas Gadjah Mada Yogyakarta. 